\title{
PENGARUH BUDAYA, SUMBERDAYA MANUSIA, DAN AGAMA TERHADAP KEMISKINAN DI KABUPATEN PIDIE JAYA
}

\author{
Benazir \\ Sekolah Tinggi Ilmu Syari'ah PTI. AL-Hilal Sigli \\ Email: benazier.hsb@gmail.com
}

\begin{abstract}
This research was conducted to determine the effect of culture, human resources and religion on poverty, with a sample of 100 people in Pidie Jaya Regency. Sampling technique using cluster sampling method. Analytical tools used are multiple linear regression and analysis path using SPSS software version 24 for windows. The criteria used in the sample selection are based on statistical data of Pidie Jaya Regency which are grouped into 3 categories, namely agriculture as much as 50 percent, trade and services sector as much as 43 percent, and the rest in the industry 7 percent. This study found that the variables of human and religious resources have a significant effect on poverty, while cultural variables have no significant effect on poverty. Indirectly, cultural variables have a significant effect on poverty that is through the variables of human resources and religious variables. The results of this study indicate that together variables culture, human resources, and religion have a significant effect on poverty in Pidie Jaya regency. Islamic Economics provides solutions to alleviate poverty in Pidie Jaya through hard work, distributing wealth through the distribution of Zakat, infaq and alms and through wakaf and through the improvement of human resources, so that poverty in Pidie Jaya regency must be considered by the government, both local government and government center.
\end{abstract}

Keywords : Culture, Human Resources, Religion, Poverty

\begin{abstract}
ABSTRAK
Penelitian ini dilakukan untuk mengetahui pengaruh budaya, sumberdaya manusia dan agama terhadap kemiskinan, dengan jumlah sampel adalah 100 orang di Kabupaten Pidie Jaya. Teknik pengambilan sampel menggunakan metode cluster sampling. Peralatan analisis yang digunakan adalah regresi linear berganda dan path analisis dengan menggunakan software SPSS versi 24 for windows. Kriteria yang digunakan dalam pemilihan sampel berdasarkan data statistik Kabupaten Pidie Jaya yang dikelompokkan kedalam 3 kategori yaitu dibidang pertanian sebanyak 50 persen, sektor perdagangan dan jasa-jasa sebanyak 43 persen, serta sisanya dibidang industri yaitu sebanyak 7 persen. Penelitian ini menemukan bahwa variabel sumber daya manusia dan agama berpengaruh signifikan terhadap kemiskinan, sedangkan variabel budaya tidak berpengaruh signifikan terhadap kemiskinan. Secara tidak langsung variabel budaya berpengaruh signifikan terhadap kemiskinan yaitu melalui variabel sumber daya manusia dan variabel agama. Hasil penelitian ini menunjukkan bahwa secara bersama-sama variabel budaya, sumber daya manusia, dan agama berpengaruh signifikan terhadap kemiskinan di Kabupaten Pidie Jaya. Ekonomi Islam memberika solusi dalam menanggulangi kemiskinan di Pidie Jaya yaitu melalui kerja keras, mendistribusikan kekayaan melalui penyaluran Zakat, infaq dan sedekah serta melalui wakaf dan melalui peningkatan sumber daya manusia, sehingga kemiskinan di Kabupaten Pidie Jaya harus diperhatikan oleh pemerintah, baik pemerintah daerah maupun pemerintah pusat.
\end{abstract}

Kata Kunci : Budaya, Sumber Daya Manusia, Agama, Kemiskinan

\section{A. PENDAHULUAN}

Kemiskinan disebut sebagai salah satu penyakit dalam ekonomi dan dianggap sebagai sumber berbagai kejahatan dan kegiatan sumbang, sehingga harus disembuhkan atau paling tidak dikurangi. Permasalahan kemiskinan memang menjadi permasalahan yang kompleks dan bersifat 
multidimensional. Oleh karena itu, upaya pengentasannya harus dilakukan secara komprehensif dengan mencakup berbagai aspek kehidupan masyarakat dan dilaksanakan secara terpadu. Islam pada dasarnya mewajibkan individu untuk bekerja dalam rangka memenuhi kebutuhan dan kesejahteraan hidup dan Islam sendiri memandang bahwa kemiskinan sepenuhnya adalah masalah struktural karena Allah telah menjamin rizki setiap makhluk yang telah, sedang, dan akan diciptakannya. Pada saat yang sama Islam telah menutup peluang bagi kemiskinan kultural dengan memberi kewajiban mencari nafkah bagi setiap individu di segala penjuru. Setiap makhluk memiliki rizkinya masing-masing, dan mereka tidak akan kelaparan.

Walaupun diketahui bahwa pemerintah selama ini telah berupaya dalam melaksanakan program pembangunan dan berbagai kebijakan untuk penanggulangan kemiskinan, namun akar permasalahan kemiskinan masih belum terpecahkan. Aceh sebagai salah satu provinsi di Indonesia, memiliki jumlah penduduk miskin sebanyak819,44 ribu jiwa (15,32 persen) pada tahun 2019. Hal ini mengalami penurunan sebesar 0,45 persen dibandingkan dengan tahun 2018 yang jumlah penduduk miskin sebanyak 839,49 ribu Jiwa (15,77 persen) (BPS, 2015). Tingginya angka tersebut hasil dari akumulasi dari angka kemiskinan kabupaten/kota di Aceh. Diantaranya kabupaten yang menyebabkan meningkatnya angka kemiskinan di Aceh adalah kabupaten Pidie Jaya sebagaisalah satu kabupaten pemekaran di Provinsi Aceh dengan Ibukotanya adalah Meureudu (BPS, 2019). Daerah tersebut adalah kabupaten dengan persentase kemiskinan terbanyak nomor empat tahun 2019 pada level provinsi yaitu sebesar 19,31 persen .

Secara umum, kemiskinan di Pidie Jaya diakibatkan oleh adanya faktor budaya yang sulit atau bahkan tidak mungkin diubah yaitu layaknya seseorang memiliki sifat malas, suka jalan pintas, sulit diajak berubah, tidak menghargai waktu, tidak hemat, dan berorientasi ke masa kini. (M. Enoch Markum, 2009). Kemiskinan seperti ini biasanya digolongkan kedalam kemiskinan yang bersifat kultural yaitu suatu kondisi kemiskinan yang terjadi karena kultur, budaya atau adat istiadat yang dianut oleh suatu kelompok masyarakat. Kelompok masyarakat seperti ini tidak mudah untuk diajak berpartisipasi dalam pembangunan, tidak mau berusaha untuk memperbaiki dan merubah tingkat kehidupannya. Akibatnya tingkat pendapatan mereka rendah menurut ukuran yang dipakai secara umum. Hal ini sejalan dengan penelitian terdahulu yakni/ budaya dapat menyebabkan mereka hidup dalam keterbelakangan, tidak maju, dan miskin. Kuatnya nilai-nilai budaya tradisional 
menyebabkan kondisi kehidupan masyarakat menjadi statis, belum mengalami deferensiasi struktural sehingga perkembangan politik, sosial, ekonomi, dan budaya tidak mengalami kemajuan yang berarti. (Abrar, 2009)

Tingginya kemiskinan di Pidie Jaya juga disebabkan oleh faktor kualitas sumber daya manusia. Untuk mengubah keterbelakangan ekonomi dan membangkitkan kemampuan dan motivasi untuk maju, maka penting untuk meningkatkan pengetahuan dan keterampilan rakyat. Pada kenyataannya tanpa perbaikan kualitas faktor manusia tidak mungkin ada kemajuan. Jadi, dapat diketahui bahwa suatu daerah itu miskin karena memiliki penduduk yang tidak berkualitas. Meskipun dilakukan pembangunan fisik seperti jalan, pabrik, rumah sakit, dan lain sebagainya, tetapi manusianya tidak berkualitas modal fisik tersebut tidak akan bisa dimanfaatkan dengan baik (Jhingan, 2007). Hal ini sesuai dengan penelitian terdahulu yaitu Indeks Pembangunan Manusia (IPM) mempunyai pengaruh paling dominan terhadap besarnya kemiskinan (Suliswanto, 2010)

Faktor lain yang juga dominan dalam menyebabkan kemiskinan di Pidie Jaya adalah faktor agama. Faktor agama dimaksud disini adalah pemahaman agama penduduk Pidie Jaya itu sendiri. Dapat dilihat dari survey awal peneliti di kabupaten Pidie Jaya yaitu kurangnya penyaluran zakat terhadap warga Pidie Jaya, hanya 4.200 orang warga yang tergolong fakir dan miskin di Pidie Jaya yang menerima zakat yang berasal dari Pegawai Negeri Sipil (PNS) dibawah Pemkab Pidie Jaya, dimana setiap fakir dan miskin mendapatkan uang tunai $\mathrm{Rp}$ 300/orang. Sedangkan jika dibandingkan dengan penduduk miskin di Pidie Jaya yaitu sebanyak 30.974 penduduk miskin pada tahun 2019. Berarti secara tidak langsung sekitar 26.774 penduduk miskin yang belum mendapatkan zakat tersebut. Untuk mengurangi kemiskinan setidaknya penyaluran zakat tersebut tidak hanya didapatkan dari golongan PNS saja, akan tetapi penyaluran zakat juga dapat disalurkan oleh pedagang yang sudah mapan atau orang-orang yang mempunyai pendapatan lebih.

Dengan mencermati kondisi dan dinamika di atas, diperlukan sebuah penelitian komprehensif mengenai pengaruh variabel budaya, sumber daya manusia dan agama terhadap kemiskinan di kabupaten Pidie Jaya dengan membatasi variabel-variabel yang telah disebutkan di atas.

\section{B. KAJIAN LITERATUR}

\section{Ruang lingkup Kemiskinan}

Kemiskinan merupakan salah satu tolak ukur kondisi sosial ekonomi dalam 
menilai keberhasilan pembangunan yang dilakukan pemerintah di suatu daerah. Dalam dimensi ekonomi kemiskinan diartikan sebagai kekurangan sumber daya yang dapat digunakan untuk meningkatkan kesejahteraan sekelompok orang, baik secara finansial maupun semua jenis kekayaan yang dapat meningkatkan kesejahteraan masyarakat. Dikategorikan miskin bilamana seseorang atau keluarga tidak dapat memenuhi kebutuhan pokok minimnya, seperti: sandang, pangan, papan, kesehatan, dan pendidikan. Dalam arti proper, kemiskinan dipahami sebagai keadaan kekurangan uang dan barang untuk menjamin kelangsungan hidup. Dalam arti luas, bahwa kemiskinan adalah suatu intergrated concept yang memiliki lima dimensi, yaitu: kemiskinan (proper), ketidakberdayaan (powerless), kerentanan menghadapi situasi darurat (state of emergency), ketergantungan (dependence), dan keterasingan (isolation) baik secara geografis maupun sosiologis.(Chambers, 1998).

Secara umum, ada dua pandangan dalam melihat kemiskinan pada suatu wilayah. Kemiskinan bisa dilihat sebagai suatu fenomena yang dipresentasikan oleh upaya yang dilakukan oleh masyarakat dalam memenuhi kebutuhan hidup mereka. Pada sisi lain, kemiskinan dilihat suatu proses. Menurut pandangan ini, eksisnya kemiskinan pada suatu wilayah merupakan akibat dari suatu proses yang sistematik yang mencakup dimensi waktu dan sistem. Kedua pandangan ini tentunya menimbulkan persepsi dan implikasi yang berbeda dalam mendesain strategi dan kebijakan penanggulangan kemiskinan (Kasim, 2006).

Kemiskinan adalah salah satu masalah sosial yang paling tua dalam sejarah kehidupan manusia. Malangnya, sampai saat ini masalah tersebut masih belum dapat diatasi sepenuhnya. Hal ini dikarenakan kemiskinan itu bersifat multidimensional artinya karena kebutuhan manusia itu bermacam-macam, maka kemiskinan pun memiliki banyak aspek primer yang berupa miskin akan aset, organisasi sosial politik, pengetahuan, keterampilan serta aspek sekunder yang berupa miskin akan jaringan sosial, sumber-sumber keuangan, dan informasi. Jika dilihat dari penyebabnya, kemiskinan terdiri dari kemiskinan natural, kemiskinan kultural, dan kemiskinan struktural (Sumodiningrat \& Gunawan, 1998). Indikator terjadinya kemiskinan berbeda-beda, sebagaimana yang telah penulis paparkan di atas, namun di bawah ini penulis akan merincikan pengertian kemiskinan menurut faktor-faktornya. Misalnya kemiskinan natural adalah kemiskinan yang disebabkan oleh faktorfaktor alamiah seperti karena cacat, sakit, usia lanjut atau karena bencana alam. Kondisi kemiskinan seperti ini disebut sebagai "Persisten Poverty" yaitu kemiskinan 
yang telah kronis atau turun temurun (Sumodiningrat \& Gunawan, 1998) Daerah seperti ini pada umumnya merupakan daerah yang kritis sumber daya alamnya ataudaerah yang terisolir.

Berbeda halnya dengan pengertian kemiskinan kultural yang mana merupakan suatu kondisi kemiskinan yang terjadi karena kultur, budaya atau adapt istiadat yang dianut oleh suatu kelompok masyarakat. Kemiskinan kultural mengacu pada sikap hidup seseorang atau kelompok masyarakat yang disebabkan oleh gaya hidup, kebiasaan hidup dan budaya di mana mereka merasa hidup berkecukupan dan tidak merasa kekurangan. Kelompok masyarakat seperti ini tidak mudah untuk diajak berpartisipasi dalam pembangunan, tidak mau berusaha untuk memperbaiki dan merubah tingkat kehidupannya. Akibatnya tingkat pendapatan mereka rendah menurut ukuran yang dipakai secara umum. Penyebab kemiskinan ini disebabkan oleh adanya faktor budaya seperti malas, tidak disiplin, boros dan lainlainnya (Sumodiningrat \& Gunawan, 1998)

Selanjutnya pengertian kemiskinan struktural adalah kemiskinan yang disebabkan oleh faktor faktor buatan manusia seperti kebijakan ekonomi yang tidak adil, distribusi aset produksi yang tidak merata, korupsi dan kolusi serta tatanan ekonomi dunia yang cenderung menguntungkan kelompok masyarakat tertentu. Munculnya kemiskinan struktural disebabkan karena berupaya menanggulangi kemiskinan natural, yaitu dengan direncanakan bermacammacam program dan kebijakan. Namun karena pelaksanaannya tidak seimbang, pemilikan sumber daya tidak merata, kesempatan yang tidak sama menyebabkan keikutsertaan masyarakat menjadi tidak merata pula, sehingga menimbulkan struktur masyarakat yang timpang (Sumodiningrat \& Gunawan, 1998)

\section{Indikator Kemiskinan}

Indikator utama kemiskinan menurut Bappenas (BAPPENAS, 2015) dapat dilihat dari terbatasnya kecukupan dan mutu pangan, dilihat daristok pangan yang terbatas, rendahnya asupan kalori penduduk miskin dan buruknyastatus gizi bayi, anak balita dan ibu. Sekitar 20 persen penduduk dengan tingkatpendapatan terendah hanya mengkonsumsi $1.571 \mathrm{kkal}$ per hari. Kekurangan asupankalori, yaitu kurang dari 2.100 kkal per hari, masih dialami oleh 60 persen penduduk berpenghasilan terendah. Dari uraian diatas, dapat disimpulkan bahwa terdapat 20 indikator utama kemiskinan menurut Bappenas di antaranya (BAPPENAS, 2015)

(1) kurangnya pangan, sandang dan perumahan yang tidak layak;

(2) terbatasnya kepemilikan tanah dan alatalat produktif; 
(3) kuranya kemampuan membaca dan menulis;

(4) kurangnya jaminan dan kesejahteraan hidup;

(5) kerentanan dan keterpurukan dalam bidang sosial dan ekonomi;

(6) ketakberdayaan atau daya tawar yang rendah;

(7) akses terhadap ilmu pengetahuan yang terbatas;

(8) terbatasnya kecukupan dan mutu pangan;

(9) terbatasnya akses dan rendahnya mutu layanan kesehatan;

(10) terbatasnya akses dan rendahnya mutu layanan pendidikan;

(11) terbatasnya kesempatan kerja dan berusaha;

(12) lemahnya perlindungan terhadap aset usaha, dan perbedaan upah;

(13) terbatasnya akses layanan perumahan dan sanitasi;

(14) terbatasnya akses terhadap air bersih;

(15) lemahnya kepastian kepemilikan dan penguasaan tanah;

(16) memburuknya kondisi lingkungan hidup dan sumberdaya alam, serta terbatasnya akses masyarakat terhadap sumber daya alam;

(17) lemahnya jaminan rasa aman;

(18) lemahnya partisipasi;

(19) besarnya beban kependudukan yang disebabkan oleh besarnya tanggungan keluarga;
(20) tata kelola pemerintahan yang buruk yang menyebabkan inefisiensi dan inefektivitas dalam pelayanan publik, meluasnya korupsi dan rendahnya jaminan sosial terhadap masyarakat.

Sedangkan indikator kemiskinan menurut World Bank (2002) yaitu:

a) Kepemilikan tanah dan modal yang terbatas;

b) Terbatasnya sarana dan prasarana yang dibutuhkan;

c) Perbedaan kesempatan di antara anggota masyarakat;

d) Perbedaan sumber daya manusia dan sektor ekonomi

e) Rendahnya produktivitas;

f) Budaya hidup yang jelek;

g) Tata pemerintahan yang buruk; dan

h) Pengelolaan sumber daya alam yang berlebihan.

\section{Pemahaman tentang Budaya}

Nilai-nilai budaya tradisional turut membentuk sikap mental masyarakat di negara sedang berkembang. Nilai budaya tradisonal tersebut adalah mentalitas masyarakat yang belum siap membangun (tidak memiliki sikap mental need for achievement) dalam segala aspek. Kemiskinan muncul sebagai akibat nilai budaya yang dianut kaum miskin itu sendiri, yang berakar dari kondisi lingkungan yang serba miskin dan diturunkan dari generasi ke generasi (cultural of poverty) (Lewis \& Oscar, 1996) Kaum miskin telah memasyarakatkan 
nilai dan perilaku kemiskinan secara turuntemurun. Akibatnya, perilaku tersebut melanggengkan kemiskinan mereka, sehingga masyarakat yang hidup dalam kebudayaan kemiskinannya sulit untuk membebaskan diri dari kemiskinan. Aspek budaya dan etnik juga berpengaruh memelihara kemiskinan, misalnya pola hidup konsumtif pada petani dan nelayan ketika panen raya, adat istiadat yang konsumtif juga banyak mewarnai masyarakat pedesaan seperti berbagai pesta rakyat atau upacara perkawinan, kelahiran, dan bahkan kematian yang dibiayai di luar kemampuan karena prestise dan keharusan budaya. Hal ini seringkali mengakibatkan suatu keluarga terlibat rentenir atau menjual harta bendanya untuk mendapatkan dana penyelenggaraan pesta (Lewis \& Oscar, 1996)

\section{Pemahaman tentang Sumber Daya}

\section{Manusia}

Sumber daya manusia merupakan istilah lain dari sumber daya insani. Kata insani berarti bersifat atau menyangkut manusia, kemanusiaan atau manusiawi. Dengan cara kemanusiaan dan memanusiakan manusia, sumber daya manusia dapat dikelola secara baik dan professional agar dapat tercipta keseimbangan antara kebutuhan sumber daya manusia dengan tuntutan serta kemajuan suatu yang diharapkan. Sumber Daya Manusia merupakan salah satu faktor yang sangat penting disamping faktor yang lain seperti modal. Oleh karena itu Sumber Daya Manusia merupakan sumber daya yang menempati posisi strategis diantara sumber daya-sumber daya lainnya yang dimiliki oleh suatu Negara. Sumber daya manusia merupakan potensi manusia yang dapat dikembangkan untuk proses produksi. Sumber daya manusia merupakan masalah yang paling penting, karena dengan sumber daya manusia menyebabkan sumber daya yang lain dapat berfungsi atau dijalankan termasuk Sumber Daya Alam (Rivai \& Sagala, 2008) .

Kemiskinan merupakan salah satu masalah makro yang menjadi pusat perhatian pemerintah di dunia termasuk negara Indonesia. Tingginya kemiskinan di suatu daerah disebabkan oleh banyak faktor, diantaranya kualitas sumber daya manusia yang dilihat dari indikator angka melek huruf dan angka harapan hidup, pertumbuhan ekonomi, dan rasio gender. Paradigma pembangunan yang sedang berkembang saat ini adalah pertumbuhan ekonomi yang di ukur dengan pembangunan manusia yang dilihat dengan tingkat kualitas hidup manusia di tiap-tiap negara. Salah satu tolok ukur yang digunakan dalam melihat kualitas hidup manusia adalah Indeks Pembangunan Manusia (IPM) yang diukur melalui kualitas tingkat pendidikan, kesehatan dan ekonomi (daya beli). Melalui peningkatan 
ketiga indikator tersebut diharapkan akan terjadi peningkatan kualitas hidup manusia. Namun demikian, keberhasilan pembangunan manusia tidak dapat dilepaskan dari kinerja pemerintah yang berperan dalam menciptakan regulasi bagi tercapainya tertib sosial (Subandi, 2012)

\section{Pemahaman tentang Agama}

Agama merupakan sesuatu yang berhubungan dengan keyakinan, keimanan dan kepercayaan seseorang. Dalam pembahasan ini, agama dipandang dan diteliti tidak secara sepihak atau memandang agamanya lebih baik dan menghina agama lain. Namun, pemahaman agama di pandang secara objektif mengenai kebenarannya dengan sikap yang relatif. Dimana jika ditinjau dari persoalan kemiskinan yang merupakan persoalan kehidupan umat manusia yang keberadaannya telah menjadi bagian dari takdir Tuhan. Namun manusia sendiri yang menentukan pada posisi mana dia berada. Kemiskinan sering disebabkan oleh faktor kultural dan struktural, oleh karenanya analisisnya pun hendaklah melalui pendekatan kultural dan struktural. Salah satu cara mengatasi kemiskinan sebagai akibat dari krisis ekonomi adalah dengan menggunakan beberapa pendekatan, antara lain pendekatan sosial, agama dan kebijakan. Tulisan ini selain akan memaparkan tentang kemiskinan juga akan mencoba memahami sebab-sebab kemiskinan, dengan fokus pada kemiskinan harta dan adakah jaminan sosial di tengahtengah kehidupan mereka. "Allah tidak merubah nasib suatu kaum, jika kaum itu tidak berkeinginan untuk merubahnya". Kalimat tersebut seharusnya memberi motivasi bagi orang-orang untuk melepaskan dirinya dari kemiskinan dan keterbelakangan. Karena nilai-nilai dan norma-norma agama dan budaya mempunyai keseimbangan, dimana budaya tersebut di dalamnya di pengaruhi oleh budaya Islam, sehingga Agama Islam benar telah menjadi sumber aspirasi dalam kehidupan orang-orang masa lampau, sekarang dan akan datang. Untuk itu orangorang seharusnya menjadikan agama Islam sebagai motivator untuk meningkatkan taraf hidup, karena umat Islam sendiri menyadari bahwa bekerja adalah ibadah, artinya memperbaiki tarap hidup kepada kehidupan yang lebih layak menjadi ibadah pula. Jadi semangat kerja yang didasari nilai-nilai agama dan budaya kerja yang tinggi dapat lahirkan kesejahteraan bagi masyarakat itu sendiri. Dari sini dapat diketahui, bahwa seharusnya kedatangan Islam benar telah merubah sikap orang, menjadi orang yang kreatif dan mempunyai budaya kerja yang tinggi.

\section{METODELOGI PENELITIAN}

Penelitian ini mengenai pengaruh budaya, sumberdaya manusia dan agama 
terhadap kemiskinan di kabupaten Pidie Jaya. Peneliti melakukan studi empiris dengan obyek penelitian diseluruh kecamatan. Adapunsampel yang digunakan dalam penelitian ini sebanyak 100 orang yang dipilih dengan menggunakan metode cluster sampling,dimana peneliti berusaha menarik anggota populasi berdasarkan kelompok tertentu saja (Sugiyono, 2008).Data statistik Kabupaten Pidie Jaya menunjukkan persentase penduduk yang bekerja menurut lapangan pekerjaan utama dikelompokkan dalam 3 kategori yaitu bidang pertanian (50 persen), perdagangan dan jasa-jasa (43 persen) sisanya bidang industri (7 persen) (BPS, 2019)

Data yang digunakan dalam penelitian ini adalah data primer dan data sekunder. Data primer diperoleh dengan metode survey yaitu menggunakan daftar pertanyaan (kuesioner) yang telah disiapkan. Data sekunder diperoleh dari berbagai sumber diantaranya buku, jurnal, maupun data publikasi dari lembaga/instansi terkait yang ada hubungannya dan dapat mendukung penelitian ini. Metode analisis data yaitu dengan menggunakanalat analisis kuantitatif, korelasi, uji asumsi klasik, uji determinasi dan regresi linear berganda dengan menggunakan software SPSS versi 24for windows (Sekaran, 2004). Secara matematis, persamaan regresi berganda dapat diformulasikan sebagai berikut:

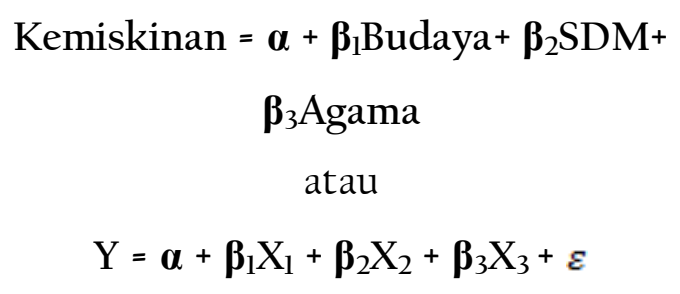

Dimana:

$\begin{array}{ll}\mathrm{Y} & =\text { Kemiskinan } \\ \alpha & =\text { Konstanta (Intercept) } \\ X_{1} & =\text { Budaya } \\ X_{2} & =\text { Sumber Daya Manusia } \\ X_{3} & =\text { Agama } \\ \beta_{1, \beta_{2,} \beta_{3}} & =\text { KoefisienRegresi } \\ \varepsilon & =\text { Errorterm }\end{array}$

\section{HASIL DAN PEMBAHASAN}

Untuk melihat ada hubungan antara budaya, SDM dan Agama terhadap kemiskinan di Kabupaten Pidie Jaya. Maka digunakan pearson korelasi, hasil perhitungan dengan bantuan SPSS diperoleh besarnya nilai koefisien korelasitersebut. Korelasi antar variabel bersifat signifikan apabila angka signifikansi diperoleh sebesar 0,00< 0,05, jika angka signifikansi < 0,05 maka hubungan antara kedua variabel signifikan (Jonathan, 2007) Untuk melihat kuat atau lemah hubungan antar variabel digunakan kriteria sebagai berikut:

$$
\begin{aligned}
& 0-0,25 \text { korelasi sangat lemah } \\
& >0,25-0,5 \text { cukup } \\
& >0,5-0,75 \text { korelasi kuat } \\
& >0,75-1 \quad \text { korelasi sangat kuat }
\end{aligned}
$$


Berdasarkan perhitungan koefisien korelasi pearson yang diperoleh pada Tabel 1 menunjukkan bahwa variabel SDM dengan Budaya, Agama dengan Budaya, Agama dengan Sumber Daya Manusia, Kemiskinan dengan Budaya, Kemiskinan dengan Sumber Daya Manusia, Kemiskinan dengan Agama berhubungan cukup kuat dan signifikan karena angka signifikansi diperoleh jauh di bawah 0,05, maka hubungan antar sesama variabel signifikan, sedangkan jika angka signifikansi diperoleh jauh diatas 0,05 atau > 0,05 maka hubungan antar sesama variabel tidak signifikan. Hasil uji koefisien korelasi pearson dapat dilihat pada tabel dibawah ini:

\section{Tabel 1.}

Koefisien Korelasi Pearson

\begin{tabular}{|l|l|l|l|l|}
\hline $\begin{array}{c}\text { Pearson } \\
\text { Correlati } \\
\text { on }\end{array}$ & Budaya & SDM & $\begin{array}{c}\text { Agam } \\
\text { a }\end{array}$ & $\begin{array}{c}\text { Kemiski } \\
\text { nan }\end{array}$ \\
\hline Budaya & 1,000 & & & \\
\hline SDM & $0,527^{* * *}$ & 1,000 & & \\
\hline Agama & $0,499^{* *}$ & $0,518^{* *}$ & 1,000 & \\
\hline $\begin{array}{l}\text { Kemiskin } \\
\text { an }\end{array}$ & $0,470^{* *}$ & $0,601^{* *}$ & \begin{tabular}{l}
$0,648^{*}$ \\
\hline
\end{tabular} & 1,000 \\
\hline
\end{tabular}

*. Menunjukkan signifikan pada level 0,01. Sumber: Data Primer, 2019 (diolah)

\section{Uji determinasi $\left(\mathrm{R}^{2}\right)$ dilakukan} untuk mengetahui seberapa besar variabel Budaya $\left(\mathrm{X}_{1}\right)$, Sumber Daya Manusia $\left(\mathrm{X}_{2}\right)$, Agama $\left(X_{3}\right)$ terhadap Kemiskinan di Kabupaten Pidie Jaya. Nilai koefisien determinasi $\left(\mathrm{R}^{2}\right)$ pada Tabel 2 untuk variabel terikat (Kemiskinan) diperoleh nilai koefisien determinasi sebesar 0,52, artinya 52\% variabel Kemiskinan dapat dijelaskan oleh perubahan-perubahan dalam variabel Budaya, Sumber Daya Manusia dan Agama. Sedangkan selebihnya yaitu sebesar 48\% dijelaskan oleh faktor-faktor variabel lain diluar daripada penelitian ini. Besarnya nilai koefisien determinasi dapat dilihat dalam tabel dibawah ini:

\section{Tabel 2.}

Model Summary Budaya, SDM, Agama mempengaruhi Kemiskinan

\begin{tabular}{|c|c|c|c|c|}
\hline \multicolumn{5}{|c|}{ Model Summary $^{\mathrm{b}}$} \\
\hline Model & $\mathrm{R}$ & $\begin{array}{c}\mathrm{R} \\
\text { Square }\end{array}$ & $\begin{array}{c}\text { Adjusted } \\
\text { R Square }\end{array}$ & $\begin{array}{c}\text { Std. Error } \\
\text { of the } \\
\text { Estimate }\end{array}$ \\
\hline $\mathrm{l}$ & $0,721^{\mathrm{a}}$ & 0,520 & 0,505 & 0,34959 \\
\hline
\end{tabular}

a. Predictors: (Constant), Agama, Budaya, Sumberdaya Manusia

b. Dependent Variable: Kemiskinan Sumber: Data Primer, 2019 (diolah)

Pengujian Asumsi klasik yang pertama diuji adalah normalitas. Residual variabel yang terdistribusi normal akan terletak disekitar garis horizontal (tidak terpencar jauh dari garis diagonal). Berdasarkan gambar normal P-P Plot yang ditunjukkan pada Gambar Imenunjukkan bahwa sebaran standardized residual berada dalam kisaran garis diagonal. Ini menunjukkan bahwa data dalam penelitian ini telah terdistribusi secara normal. Seperti terlihat pada gambar berikut: 


\section{Gambar 2. Uji Normalitas}

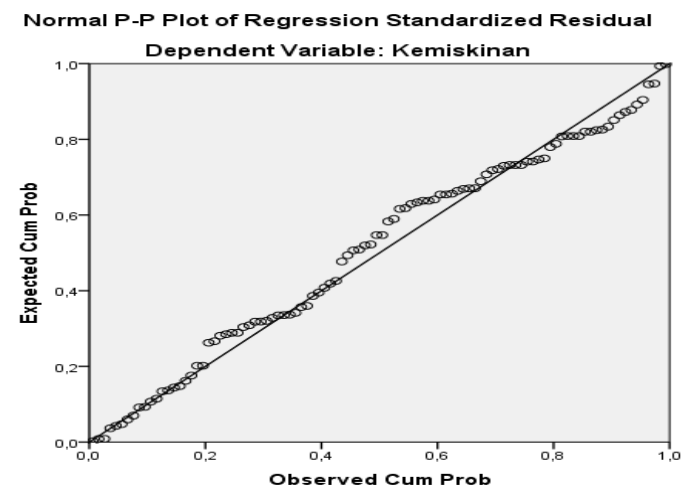

Hasil pengujuan analisis regresi linear berganda dilakukan dengan pengujian secara simultan (Uji-F) dan pengujian secara parsial (Uji-t). Pengujian secara simultan untuk melihat seberapa besar pengaruh variabel independen secara bersama-sama terhadap variabel dependen, yang ditampilkan pada Tabel 3.

Hasil pengujian secara simultan diperoleh $F_{\text {hitung }}$ sebesar 34,719, sedangkan $\mathrm{F}_{\text {tabel }}$ pada tingkat signifikansi $\alpha=5$ persen adalah sebesar 2,70, hal ini menunjukkan bahwa $F_{\text {hitung }}>F_{\text {tabel }}$ dengan tingkat signifikan sebesar 0,000. Artinya bahwa budaya, sumber daya manusia dan agama secara bersama-sama berpengaruh signifikan terhadap kemiskinan di Kabupaten Pidie Jaya yang ditunjukkan oleh nilai sig.tabeksignifikan 5 persen, yaitu $0,000<0,05$.

Tabel 3.

Analysis of Varianve (ANOVA)

\begin{tabular}{|c|c|c|c|c|c|}
\hline Model & $\begin{array}{l}\text { Sum of } \\
\text { Squares }\end{array}$ & df & $\begin{array}{l}\text { Mean } \\
\text { Square }\end{array}$ & F & Sig. \\
\hline \begin{tabular}{l|l} 
& Regression
\end{tabular} & 12,729 & 3 & 4,243 & 34,719 & $0,000^{b}$ \\
\hline Residual & 11,733 & 96 & 0,122 & & \\
\hline Total & 24,462 & 99 & & & \\
\hline
\end{tabular}

a. Dependent Variable: Kemiskinan

b. Predictors: (Constant), Agama, Budaya,

Sumberdaya Manusia

Sumber: Data Primer, 2019 (diolah)

Pengujian secara parsial (Uji-t)

untuk mengetahui pengaruh ketiga variabel terhadap Kemiskinan di kabupaten Pidie Jaya yang ditampilkan pada tabel berikut:

Tabel 4.

Pengaruh Budaya, SDM dan Agama terhadap Kemiskinan di Kabupaten Pidie Jaya

\begin{tabular}{|c|c|c|c|c|c|c|}
\hline & \multirow[t]{2}{*}{ Model } & \multicolumn{2}{|c|}{$\begin{array}{l}\text { Unstandardize } \\
\text { d Coefficients }\end{array}$} & \multirow{2}{*}{$\begin{array}{l}\text { Standa } \\
\text { rdized } \\
\text { Coeffic } \\
\text { ients } \\
\text { Beta }\end{array}$} & \multirow[t]{2}{*}{$t$} & \multirow[t]{2}{*}{ Sig. } \\
\hline & & B & $\begin{array}{l}\text { Std. } \\
\text { Error }\end{array}$ & & & \\
\hline \multirow[t]{4}{*}{1} & $\begin{array}{l}\text { (Constan } \\
\text { t) }\end{array}$ & 0,271 & 0,384 & & 0,707 & 0,481 \\
\hline & Budaya & 0,090 & 0,105 & 0,075 & 0,860 & 0,392 \\
\hline & $\begin{array}{l}\text { Sumberd } \\
\text { aya } \\
\text { Manusia }\end{array}$ & 0,367 & 0,097 & 0,335 & 3,779 & 0,000 \\
\hline & Agama & 0,455 & 0,091 & 0,437 & 5,032 & 0,000 \\
\hline
\end{tabular}

Dependent Variable: Kemiskinan

Sumber: Data Primer, 2019 (diolah)

Dari hasil perhitungan statistik dengan menggunakan bantuan program SPSSseperti terlihat pada Tabel 4 di atas, maka diperoleh persamaan regresi berganda sebagai berikut:

$$
Y=0,271+0,090 X_{1}+0,0367 X_{2}+0,455 X_{2}
$$

Berdasarkan hasil analisis regresi linear berganda dapat diketahui bahwa kedua variabel yang diteliti Sumber Daya Manusia dan Agama secara parsial 
berpengaruh positif dan signifikan pada level signifikansi 5 persen terhadap Kemiskinan di Kabupaten Pidie Jaya. Dari ketiga variabel tersebut hanya variabel budaya yang tidak signifikan terhadap kemiskinan di kabupaten Pidie Jaya. Sehingga akan dilakukan pengujian data kembali, dimana budaya dijadikan sebagai intervening variabel (variabel penting) yaitu suatu variabel yang menghubungkan antara variabel independen dengan variabel dependen, karena mengingat kemiskinan dapat muncul sebagai akibat adanya nilainilai atau kebudayaan yang dianut oleh orang-orang miskin, seperti mudah menyerah pada nasib serta kurang memiliki etos kerja.

Untuk melihat pengaruh variabel independen terhadap variabel dependen secara parsial disini akan digunakanan alisis jalur (path analysis) merupakan suatu teknik untuk menganalisis hubungan sebab akibat yang terjadi pada regresi berganda jika variabel bebasnya mempengaruhi variabel terikat tidak hanya secara langsung, tetapi juga secara tidak langsung (Jonathan, 2007). Manfaat dari path analysis adalah perluasan dari persamaan regresi sederhana atau berganda yang diperlukan pada jalur hubungan (network) variable-variabel yang melibatkan lebih dari satu. Angka Beta atau Standardized Coefficients digunakan untuk melihat besarnya pengaruh, seperti terlihat pada Tabel 5 menunjukkan pengaruh budaya terhadap kemiskinan di kabupaten Pidie Jaya melalui SDM, dan Tabel 6 menunjukkan pengaruh budaya terhadap kemiskinan di Kabupaten Pidie Jaya melalui Agama.

\section{Tabel 5.}

Pengaruh Budaya terhadap Kemiskinan di Kabupaten Pidie Jaya melalui Sumber Daya Manusia

\begin{tabular}{|c|c|c|c|c|c|}
\hline \multirow[t]{2}{*}{ Model } & \multicolumn{2}{|c|}{$\begin{array}{l}\text { Unstandardi } \\
\text { zed } \\
\text { Coefficients }\end{array}$} & \multirow{2}{*}{\begin{tabular}{|c|}
$\begin{array}{c}\text { Standardi } \\
\text { zed } \\
\text { Coefficien } \\
\text { ts }\end{array}$ \\
Beta \\
\end{tabular}} & \multirow[t]{2}{*}{$\mathrm{t}$} & \multirow[t]{2}{*}{ Sig. } \\
\hline & B & $\begin{array}{c}\text { Std. } \\
\text { Error }\end{array}$ & & & \\
\hline $\begin{array}{l}\text { (Constan } \\
\text { t) }\end{array}$ & 0,722 & 0,417 & & $\begin{array}{c}1,73 \\
0\end{array}$ & $\begin{array}{c}0,08 \\
7\end{array}$ \\
\hline Budaya & 0,254 & 0,112 & 0,212 & $\begin{array}{l}2,2 \\
80\end{array}$ & $\begin{array}{l}0,0 \\
25 \\
\end{array}$ \\
\hline \begin{tabular}{|l|} 
Sumberd \\
aya \\
Manusia
\end{tabular} & 0,536 & 0,102 & 0,489 & $\begin{array}{l}5,2 \\
62\end{array}$ & $\begin{array}{l}0,0 \\
00\end{array}$ \\
\hline
\end{tabular}

a. Dependent Variable: Kemiskinan

Sumber: Data Primer, 2019 (diolah)

Tabel 6.

Pengaruh Budaya terhadap Kemiskinan di Kabupaten Pidie Jaya melalui Agama

\begin{tabular}{|c|c|c|c|c|c|}
\hline \multirow[t]{2}{*}{ Model } & \multicolumn{2}{|c|}{$\begin{array}{l}\text { Unstandardi } \\
\text { zed } \\
\text { Coefficients }\end{array}$} & \multirow{2}{*}{$\begin{array}{c}\text { Standardi } \\
\text { zed } \\
\text { Coefficien } \\
\text { ts }\end{array}$} & \multirow[t]{2}{*}{$\mathrm{t}$} & \\
\hline & B & $\begin{array}{c}\text { Std. } \\
\text { Error }\end{array}$ & & & \\
\hline $\begin{array}{l}\text { (Consta } \\
\text { nt) }\end{array}$ & 0,741 & 0,387 & & $\begin{array}{c}1,91 \\
5\end{array}$ & $\begin{array}{c}0,05 \\
8 \\
\end{array}$ \\
\hline Budaya & 34 & 0,104 & 0,195 & $\begin{array}{c}2,24 \\
4\end{array}$ & 0,02 \\
\hline Agama & 0,574 & 0,091 & 0,551 & $\begin{array}{c}6,33 \\
7\end{array}$ & $\begin{array}{c}0,00 \\
0\end{array}$ \\
\hline
\end{tabular}

a. Dependent Variable: Kemiskinan

Sumber: Data Primer, 2019 (diolah)

Karena menggunakan analisis jalur maka nilai koefisien dilihat pada kolom standardized coefficients beta, pada tabel 5 hasil penelitian terhadap variabel budaya melalui variabel Sumber Daya Manusia 
menunjukkan bahwa signifikansi sebesar 0,025 atau probabilitas jauh dibawah $\alpha=$ 0,05. Dengan demikian hasil perhitungan statistik menunjukkan bahwa secara parsial variabel budaya berpengaruh positif dan signifikan terhadap kemiskinan di Pidie Jaya secara tidak langsung melalui variabel Sumber Daya Manusia. Sedangkan hasil penelitian pada tabel 6 menunjukkan hasil bahwa variabel budaya melalui variabel Agama memperoleh nilai signifikansi sebesar 0,027 atau probabilitas jauh dibawah $\alpha=0,05$. Dengan demikian hasil perhitungan statistik menunjukkan bahwa secara parsial variabel budaya berpengaruh positif dan signifikan terhadap kemiskinan di Pidie Jaya secara tidak langsung melalui variabel Agama.

Hasil di atas tersebut menunjukkan secara tidak langsung variabel budaya mempengaruhi kemiskinan melalui variabel SDM dan agama. Artinya bahwa variabel budaya juga mempunyai pengaruh yang besar terhadap kemiskinan, walaupun pengaruhnya secara tidak langsung. Perhitungan lengkap pengaruh langsung dan tidak langsung dapat dilihat pada tabel 7 di bawah ini:

\section{Tabel 7.}

Tabel Pengaruh Langsung dan Tidak Langsung variabel Budaya, Sumber Daya Manusia dan Agama terhadap Kemiskinan di Kabupaten Pidie Jaya

\begin{tabular}{|l|c|c|c|}
\hline & & Langsung & \\
\hline $\begin{array}{l}\text { Pengaruh } \\
\text { Budaya terhadap } \\
\text { Kemiskinan }\end{array}$ & $\begin{array}{c}0,075 \mathrm{x} \\
0,075\end{array}$ & 0,006 \\
\hline $\begin{array}{l}\text { Pengaruh SDM } \\
\text { terhadap } \\
\text { Kemiskinan }\end{array}$ & $\begin{array}{c}0,335 \mathrm{x} \\
0,335\end{array}$ & 0,112 \\
\hline $\begin{array}{l}\text { Pengaruh Agama } \\
\text { terhadap } \\
\text { Kemiskinan }\end{array}$ & $\begin{array}{c}0,437 \mathrm{x} \\
0,437\end{array}$ & 0,191 \\
\hline \multicolumn{2}{|c|}{ Total Pengaruh Langsung } & 0,309 \\
\hline $\begin{array}{l}\text { Pengaruh } \\
\text { Budaya terhadap } \\
\text { Kemiskinan } \\
\text { Melalui SDM }\end{array}$ & $0,212 \mathrm{x}$ & 0,104 \\
\hline $\begin{array}{l}\text { Pengaruh } \\
\text { Budaya terhadap } \\
\text { Kemiskinan } \\
\text { Melalui Agama }\end{array}$ & 0,489 & $0,195 \mathrm{x}$ & 0,107 \\
\hline \multicolumn{3}{|c|}{ Total Pengaruh tidak Langsung } & 0,211 \\
\hline \multicolumn{3}{|c|}{ Total Semua Pengaruh } & 0,520 \\
\hline
\end{tabular}

Sumber: Sumber: Data Sekunder, 2019 (diolah)

Untuk melihat pengaruh variabel budaya, sumberdaya manusia dan agama terhadap kemiskinan di kabupaten Pidie Jaya secara langsung dan tidak langsung di gambarkan sebagai berikut pada gambar 2 berikut:

\section{Gambar 2.}

pengaruh variabel budaya, sumberdaya manusia dan agama terhadap kemiskinan

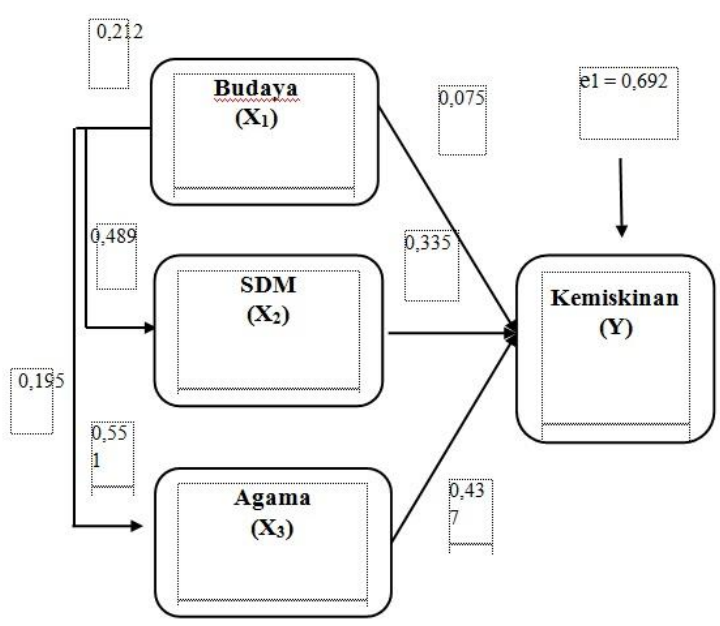

\begin{tabular}{|c|c|c|c|}
\hline $\begin{array}{c}\text { Pengaruh } \\
\text { Variabel }\end{array}$ & $\begin{array}{c}\text { Pengaruh } \\
\text { Langsung }\end{array}$ & $\begin{array}{c}\text { Pengaruh } \\
\text { Tidak }\end{array}$ & Total \\
\hline
\end{tabular}


Secara keseluruhan dapat dibuktikan bahwa ketiga variabel berpengaruh signifikan terhadap kemiskinan di kabupaten Pidie Jaya hanya saja pengaruh tersebut secara langsung maupun secara tidak langsung, variabel yang berpengaruh langsung terhadap kemiskinan adalah variabel sumber daya manusia dan variabel agama, sedangkan variabel budaya berpengaruh secara tidak langsung terhadap kemiskinan yaitu melalui variabel sumber daya manusia dan variabel agama.

Dalam pengujian analisis jalur juga digunakan pengujian secara stimultan untuk melihat seberapa besar pengaruh variabel independen secara bersama-sama terhadap variabel dependen. Hasilnya menunjukkan bahwasecara bersama-sama berpengaruh positif dan signifikan terhadap kemiskinan seperti terlihat pada tabel 8 dan tabel 9 dibawah ini:

Tabel 8.

Analysis Of Variance (ANOVA) Pengaruh tidak Langsung Budaya terhadap Kemiskinan melalui Sumber Daya Manusia

\begin{tabular}{|c|l|c|c|c|c|c|}
\hline \multicolumn{2}{|c|}{ Model } & $\begin{array}{c}\text { Sum of } \\
\text { Squares }\end{array}$ & df & $\begin{array}{c}\text { Mean } \\
\text { Square }\end{array}$ & F & Sig. \\
\hline \multirow{2}{*}{1} & Regression & 9,635 & 2 & 4,818 & 31,517 & $0,000^{b}$ \\
\cline { 2 - 7 } & Residual & 14,827 & 97 & 0,153 & & \\
\cline { 2 - 7 } & Total & 24,462 & 99 & & & \\
\hline
\end{tabular}

a. Dependent Variable: Kemiskinan

b. Predictors: (Constant), Sumberdaya Manusia, Budaya

Tabel 9.

ANOVAPengaruh tidak Langsung Budaya terhadap Kemiskinan melalui Agama

\begin{tabular}{|l|l|c|c|c|c|c|}
\hline \multicolumn{2}{|c|}{ Model } & $\begin{array}{c}\text { Sum of } \\
\text { Square } \\
\text { s }\end{array}$ & df & $\begin{array}{c}\text { Mean } \\
\text { Squar } \\
\text { e }\end{array}$ & F & Sig. \\
\hline 1 & $\begin{array}{l}\text { Regressio } \\
\mathrm{n}\end{array}$ & 10,984 & 2 & 5,492 & $\begin{array}{c}39,52 \\
4\end{array}$ & $\begin{array}{c}0,000 \\
\mathrm{~b}\end{array}$ \\
\hline
\end{tabular}

\begin{tabular}{|l|l|c|c|c|l|l|}
\hline Residual & 13,478 & 97 & 0,139 & & \\
\hline Total & 24,462 & 9 & & & \\
& & 9 & & & \\
\hline
\end{tabular}

a. Dependent Variable: Kemiskinan

b. Predictors: (Constant), Agama, Budaya

E. PENUTUP

\section{Kesimpulan}

Hasil pengujian secara parsial (Uji-t) bahwa variabel budaya berpengaruh positif dan tidak signifikan terhadap kemiskinan di Kabupaten Pidie Jaya. Sedangkan variabel sumber daya manusia dan agama berpengaruh positif dan signifikan terhadap kemiskinan di kabupaten Pidie Jaya. Secara tidak langsung variabel budaya berpengaruh signifikan terhadap kemiskinan yaitu melalui variabel sumberdaya manusia dan variabel agama. Pengujian secara stimultan (Uji-F) variabel budaya, sumber daya manusia dan agama secara bersama-sama berpengaruh signifikan terhadap kemiskinan di Kabupaten Pidie Jaya. Nilai koefisien determinasi $\left(\mathrm{R}^{2}\right)$ untuk variabel kemiskinan dapat dijelaskan oleh perubahan-perubahan dalam variabel budaya, sumber daya manusia dan agama sebesar 52\%. Sedangkan selebihnya yaitu sebesar 48\% dijelaskan oleh faktor-faktor variabel lain diluar dari pada penelitian ini. Dalam menanggulangi kemiskinan di kabupaten Pidie Jaya beberapa solusi yang ditawarkan oleh ekonomi islam adalah kerja keras, mendistribusikan kekayaan melalui penyaluran Zakat, infaq dan sedekah serta melalui wakaf, selain itu Islam juga 
menawarkan solusi melalui peningkatan Sumber Daya Manusia yaitu melalui pendidikan, karena Islam sendiri memandang bahwa ilmu merupakan dasar penentuan martabat dan derajat seseorang dalam kehidupan.

\section{Saran}

a. Pemerintah (pusat dan daerah) perlu menyadari sepenuhnya bahwa kemiskinan harus diberantas agar penduduk rentan tidak jatuh menjadi penduduk miskin. Dengan prinsip penyelenggaraan terkoordinasi dan bersifat saling melengkapi antara pusat dan daerah, maka salah satu upaya yang perlu dijalankan oleh pemerintah daerah adalah menutupi kekosongan yang tidak dilaksanakan oleh Pemerintah pusat.

b. Penelitian ini hanya membahas tentang kemiskinan di Kabupaten Pidie Jaya. Sebaiknya penelitian selanjutnya juga dapat membandingkan kemiskinan kemiskinan di Kabupaten, Provinsi bahkan Negara lainnya.

c. Untuk penelitian selanjutnya sebaiknya menambahkan jumlah sampel dengan waktu pengamatan yang lebih lama sehingga hasil yang diperoleh akan lebih dapat digeneralisasikan serta lebih mendukung.

\section{DAFTAR PUSTAKA}

Abrar, M. (2009). Analisis Kemiskinan Penduduk di Kabupaten Pidie Jaya Provinsi Nanggro Aceh Darussalam. Jakarta: Indonesian Science and Technology Digital Library.

BAPPENAS. (2015). Pengertian Kemiskinan. Jakarta.

BPS. (2015). Seksi Neraca Wilayah dan Analisis Statistik, Kecamatan Ulim dalam Angka 2015. Meureudu.

BPS. (2019). Statistik Daerah Kabupaten Pidie Jaya. Pidie Jaya.

Chambers. (1998). Pembangunan Desa Mulai dari Belakang. Jakarta: LP3ES.

Jhingan, M. L. (2007). Ekonomi Pembangunan dan Perencanaan. Jakarta: Radja Grafindo Persada.

Jonathan, S. (2007). Analisis Jalur untuk Riset Bisnis dengan SPSS. Yogyakarta: ANDI.

Kasim, M. (2006). Karakteristik Kemiskinan dan Strategi Penanggulangannya. Jakarta: Indomedia.

Lewis, \& Oscar. (1996). Kebudayaan Kemiskinan dalam Parsudi Suparlan, Kemiskinan di Perkotaan. Jakarta: Yayasan Obor Indonesia.

M. Enoch Markum. (2009). Pengentasan Kemiskinan dan Pendekatan Psikologi Sosial. Psikobuana, 1(1), 1-12.

Rivai, V., \& Sagala, E. J. (2008). Manajemen Sumber Daya Manusia Untuk Perusahaan. Jakarta: Rajawali Pers.

Sekaran. (2004). Metodologi Penelitian Untuk Bisnis. Bandung: Salemba Empat.

Subandi. (2012). Ekonomi Pembangunan. Bandung: Alfabeta.

Suliswanto, M. S. W. (2010). Pengaruh 
Produk Domestik Bruto (PDB) Dan Indeks Pembangunan Manusia (IPM) Terhadap Angka Kemiskinan Di Indonesia. Jurnal Ekonomi Pembangunan, $8(2), 357-366$.

Sumodiningrat, \& Gunawan. (1998). Membangun Perekonomian Rakyat.

Yogyakarta: Pustaka Pelajar 